\title{
Assessment of the phytochemical constituents and antioxidant activity of a bloom forming microalgae Euglena tuba
}

\author{
Dipankar Chaudhuri ${ }^{1}$, Nikhil Baban Ghate${ }^{1}$, Shampa Deb², Sourav Panja ${ }^{1}$, Rhitajit Sarkar $^{1}$, Jayashree Rout ${ }^{2}$ \\ and Nripendranath Mandal ${ }^{1 *}$
}

\begin{abstract}
Background: Unstable generation of free radicals in the body are responsible for many degenerative diseases. A bloom forming algae Euglena tuba growing abundantly in the aquatic habitats of Cachar district in the state of Assam in North-East India was analysed for its phytochemical contents, antioxidant activity as well as free radical scavenging potentials.

Results: Based on the ability of the extract in $\mathrm{ABTS}^{++}$radical cation inhibition and $\mathrm{Fe}^{3+}$ reducing power, the obtained results revealed the prominent antioxidant activity of the algae, with high correlation coefficient of its TEAC values to the respective phenolic and flavonoid contents. The extract had shown its scavenging activity for different free radicals and $41.89 \pm 0.41 \mu \mathrm{g} / \mathrm{ml}, 5.83 \pm 0.07 \mu \mathrm{g} / \mathrm{ml}, 278.46 \pm 15.02 \mu \mathrm{g} / \mathrm{ml}$ and $223.25 \pm 4.19 \mu \mathrm{g} / \mathrm{ml}$ were determined as the $I_{50}$ values for hydroxyl, superoxide, nitric oxide and hypochlorous acid respectively, which are lower than that of the corresponding reference standards. The phytochemical analysis also revealed that the phenolics, flavonoids, alkaloids, tannins and carbohydrates are present in adequate amount in the extract which was confirmed by HPLC analysis.
\end{abstract}

Conclusions: The results showed that $70 \%$ methanol extract of the algae possesses excellent antioxidant and free radical scavenging properties.

Keywords: Euglenoid, Phytochemicals, Free radical scavenging, Antioxidant, Reducing power

\section{Background}

Euglena tuba (Carter) (Family - Euglenaceae) is an unicellular euglenozoa distributed in most aquatic bodies all over India throughout the year, with the prominent seasonal algal bloom of Euglena occurring in the winter season. In general, algal bloom is an incidental event which tends to occur when a period of calm weather coincides with nutrient enrichment and excess buoyancy of the population of algal cells. Early reports of red coloured euglenozoa blooms from India were recognised as Euglena tuba, E. orientalis and E. haematodes [1]. Recent researches have demonstrated that a number of bloom forming

\footnotetext{
*Correspondence: mandaln@rediffmail.com

'Division of Molecular Medicine, Bose Institute, P-1/12 CIT Scheme VIIM, Kolkata 700054, India

Full list of author information is available at the end of the article
}

algae like Dunaliella, Chlorella, Chlamydomonas, Ochromonas, Spirulina and Euglena have attracted immense attention for their significant antioxidant properties [2-5]. Different species of Euglena has been screened for their simultaneous production of more than a single antioxidant compound like $\beta$-carotene, vitamin $C$ and vitamin $\mathrm{E}$, rendering it a promising dietary supplement [6]. Since Euglena being non-toxic and does not pose any threat to the ecosystem, it presents an interesting arena for exploring the beneficial potential of this alga.

Unbalanced generation of free radicals in the body plays key role in causing many degenerative diseases such as cancer, cardiovascular disease, arthritis and neurodegenerative disorder by damaging cellular DNA, proteins and lipids [7]. Antioxidants are capable of neutralizing free radicals prior to their detrimental physiological effect [8]. Synthetic antioxidants such as butylated hydroxytoluene 
and butylated hydroxyanisole have recently been reported to have adverse side effects in human health $[9,10]$. The search for effective natural antioxidants in food, cosmetic and therapeutic industry is fast emerging as a promising alternative for synthetic antioxidants in respect of low cost, high compatibility with dietary intake and almost zero side effects $[5,11]$. Although antioxidant properties of various terrestrial plants are well recognized, corresponding aspects of algae and particularly of E. tuba has not been adequately addressed. Therefore the present study is aimed to assess the phytochemical compositions and evaluate antioxidant potential and free radical scavenging activity of a $70 \%$ methanol extract of E. tuba (ETME).

\section{Results and discussion}

\section{Algal characterisation}

The microscopic observation of cell morphology such as the size of the organism, presence or absence of chloroplast, eyespot, flagella, paramylon bodies etc. were taken into account and identified as Euglena tuba (Carter). Microscopic observation of random samples after centrifugation assured that the samples were free from any other algae as well as phytoplankton contaminations which was supported by previous reports that the blooms of Euglena species occur at higher temperature, lower dissolved oxygen and acidic environment with higher nutrient concentration which have significantly inhibit the growth of other algal species and phytoplankton [12-15].

\section{Phytochemical analysis}

Several studies have been made on biological activities of algae and their substance, which could be potential rich sources of natural antioxidants [16]. Das et al. [17] have described the antibacterial potential of the freshwater alga Euglena viridis (Ehren). Recently, Euglena gracilis $\mathrm{Z}$ wild type has already been considered a potential source of vitamin E [18]. Medicinal algae are used as food, flavours, cosmetics, fumigants and insect deterrents, while being the best resources from which novel bioactive compounds are discovered [19]. Qualitative screening of phytochemicals from the algal extract was summarized in Table 1 . The results revealed the presence of medically active compounds such as alkaloids, carbohydrates, flavonoids, phenols, saponins, tannins and terpenoids. From Table 1 it was found that the extract contained highest amount of flavonoids, with considerable amounts of alkaloids, phenolics, tannins, reduced carbohydrates and low amount of ascorbic acid content. HPLC analysis was then performed to identify the presence of bioactive compounds by comparing the retention time of reference compounds under the same condition, six main peaks having retention times 3.74, 5.95, 14.27, 18.08, 24.48 and $66.96 \mathrm{~min}$ were appeared on the chromatogram of HPLC analysis which were determined to be corresponding to tannic acid, reserpine, methyl gallate, catechin, ascorbic acid and rutin respectively (Figure 1). Most commonly known phytochemicals with antioxidant property are phenolics, flavonoids and tannins which counteract the body's reactions to allergens, viruses and carcinogens. They show many useful therapeutic roles such as antiallergic, anti-inflammatory, antimicrobial and anticancer activity [20]. Nitrogen containing organic compounds and alkaloids (such as reserpine) are physiologically active with sedative and analgesic properties and used in relieving pains, anxiety and depression [21]. Glycosides are compounds containing a carbohydrate and non-carbohydrate residue (moiety) in the same molecule. These compounds can be used in the treatment of congestive heart failure and cardiac arrhythmia [20]. Also, the carbohydrates in food are of major interest in relation to chronic diseases. Different types of carbohydrates give rise to different glycemic responses and also able to stimulate lipogenesis $[22,23]$. Ascorbic acid, derived from glucose is well established as a naturally occurring antioxidant also reported to attenuate hepatic damage [24]. The obtained results in this study suggested that the identified phytochemical compounds may be the bioactive constituents and this unicellular Euglena is proving to be a valuable reservoir of bioactive compounds of substantial medicinal merit.

\section{Correlation of antioxidant activity to the phytochemical contents}

The antioxidant activity of ETME was measured by using two methods that are complementary to each other, viz., TEAC through $\mathrm{ABTS}^{\bullet+}$ radical cation scavenging and reducing power capacity. The assays give an overall picture of the antioxidative ability of the plant extract as

Table 1 Qualitative and quantitative phytochemical analysis of $E$. tuba extract

\begin{tabular}{|c|c|c|c|c|c|c|c|c|c|c|c|}
\hline \multirow[t]{2}{*}{ Tests } & \multicolumn{11}{|c|}{ Phytochemicals } \\
\hline & Phen & Flav & Carbo & Tan & Alka & Asc & Ter & Triter & Anth & Sap & Gly \\
\hline Qualitative & + & + & + & + & + & + & + & + & - & + & - \\
\hline Quantitative & $11.15 \pm 0.001$ & $100.78 \pm 2.114$ & $9.99 \pm 0.022$ & $5.6 \pm 0.047$ & $2.95 \pm 0.3$ & $2.16 \pm 0.059$ & & & & & \\
\hline
\end{tabular}

Phen- Phenol, Flav- Flavonoid, Carbo- Carbohydrate, Tan- Tannin, Alka- Alkaloid, Asc-Ascorbic acid, Ter- Terpenoids, Triter- Triterpenoids, Anth- Anthraquinones, Sap- Saponin, Gly- Glycoside; Total phenolics (mg/100 mg extract gallic acid equivalent), Total flavonoids (mg/100 mg extract quercetin equivalent), Carbohydtrate (mg/100 mg extract glucose equivalent), Tannin (mg/100 mg extract catechin equivalent), Alkaloids (mg/100 mg extract reserpin equivalent), Ascorbic acid (mg/ $100 \mathrm{mg}$ extract ascorbic acid equivalent). " + " Represents presence of the phytoconstituent; "-" represents absence of the phytoconstituent. 


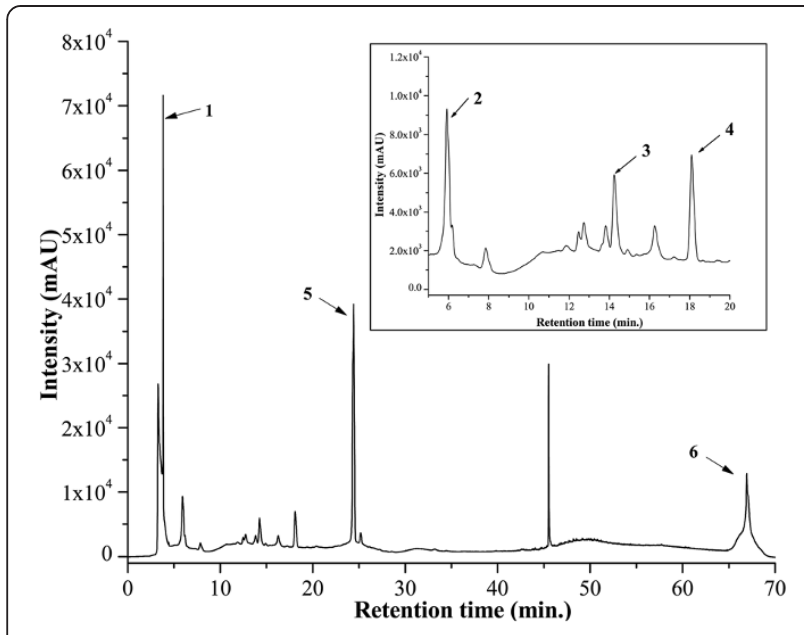

Figure 1 HPLC chromatogram of ETME. Inset shows the expanded region of the chromatogram with retention time of 5-20 min. Peaks marked signify the retention peak of (1) tannic acid (3.74), (2) reserpine (5.95), (3) methyl gallate (14.27), (4) catechin (18.08), (5) ascorbic acid (24.48) and (6) rutin (66.96 $\mathrm{min}$ ) respectively.

summarized in the Figures 2 and 3 along with Table 2 . Between the assays, $\mathrm{ABTS}^{*+}$ assay is based on interaction between hydrogen-donating and chain-breaking antioxidants and which has a characteristic blue colour showing absorption maxima at $734 \mathrm{~nm}$. Interaction with the extract or standard trolox suppressed the absorbance of the $\mathrm{ABTS}^{\circ+}$ radical cation in a dose dependant manner and the results, expressed as percentage inhibition of absorbance, are shown in Figure 2(a) and 2(b) respectively. Previous research has revealed that there is a linear correlation between antioxidant activity and reducing power [25]. The presence of antioxidants in the sample would result in the reducing of $\mathrm{Fe}^{3+}$ to $\mathrm{Fe}^{2+}$ by donating an electron. As illustrated in Figure 3, $\mathrm{Fe}^{3+}$ to $\mathrm{Fe}^{2+}$ transformation in the presence of the extract and reference ascorbic acid was found increasing with increasing concentrations. Although the activity of ascorbic acid was better than the sample, the latter showed significantly low reducing capability which may serve as a significant indicator of its antioxidant potential.

Since the antioxidant property of natural antioxidants is generally attributed to their phytochemical constituents, TEAC value of ETME was correlated to its total phenolic and flavonoid content. As shown in Figure 4(a), the total phenolic content of ETME significantly correlated with antioxidant activity (correlation coefficient $R=0.9881$ ), which proved that the phenolic content of ETME highly ascertained the antioxidant activity. Alongside, the correlation coefficient of ETME for flavonoid content with its antioxidant capacity was highly significant (correlation coefficient $R=0.9486$ ), correlated with their antioxidant activity (Figure 4(b)).

\section{DPPH radical scavenging assay}

DPPH free radical is commonly used to determine radical scavenging activity of natural compounds due to its stable nature. DPPH in its radical form absorbs at $517 \mathrm{~nm}$, but upon reduction with an antioxidant, its absorption decreases due to the formation of its non-radical form, DPPH-H [26]. Thus, the radical scavenging activity in the presence of a hydrogen donating antioxidant can be monitored as a decrease in absorbance of DPPH solution. ETME showed excellent dose-dependent scavenging activity of DPPH radical (Figure 5) but lower than the standard ascorbic acid. The $\mathrm{IC}_{50}$ values (Table 2) of the extract and standard ascorbic acid were 146.07 \pm $1.80 \mu \mathrm{g} / \mathrm{ml}$ and $5.29 \pm 0.28 \mu \mathrm{g} / \mathrm{ml}$ respectively.

\section{Scavenging of Reactive Oxygen Species (ROS)}

Hydroxyl radical, the most detrimental ROS induces several damages to DNA, lipids and proteins [27]. It can also accelerate lipid peroxidation by decomposing lipid hydroperoxides into proxy and alkoxyl radicals that can perpetuate the chain reaction [28]. The ability of the extract to inhibit hydroxyl radical-mediated deoxyribose degradation in a $\mathrm{Fe}^{3+}$-EDTA-ascorbic acid and $\mathrm{H}_{2} \mathrm{O}_{2}$
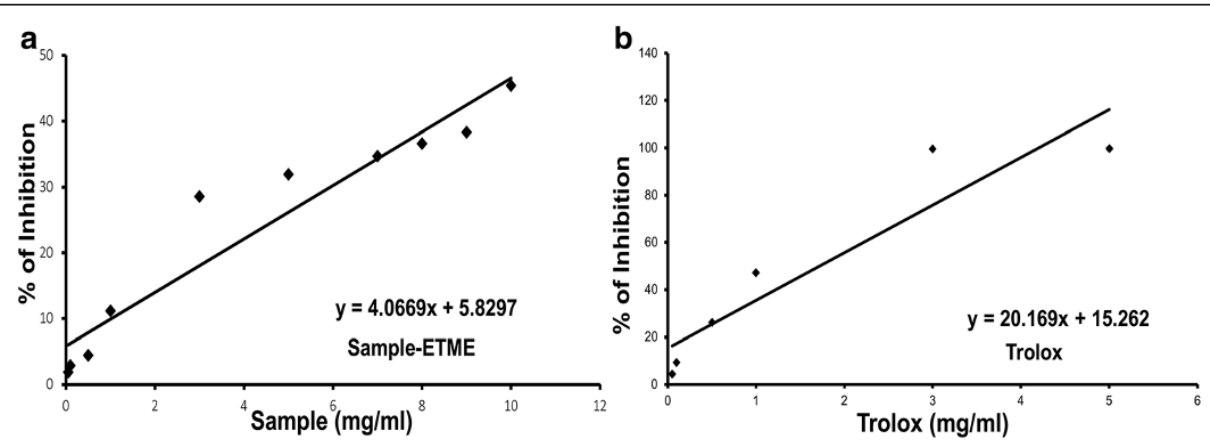

Figure 2 Total antioxidant activity of ETME (a) and reference compound trolox (b) on ABTS radical cation decolorization assay. The percentage of inhibition was plotted against concentration of sample. All data are expressed as mean \pm S.D. $(n=6)$. 


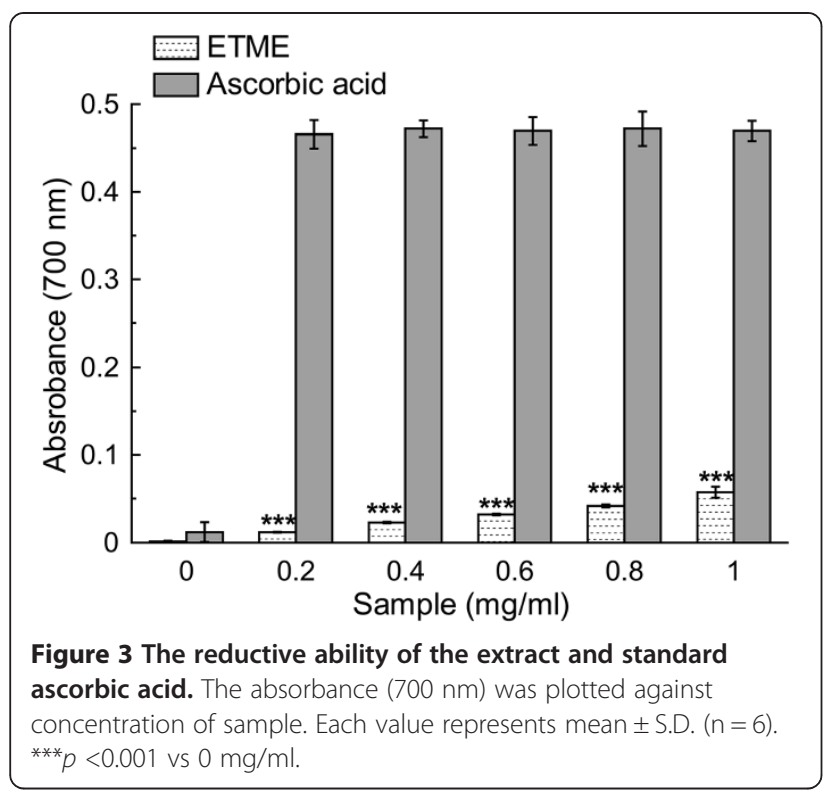

reaction mixture was exhibited in hydroxyl radical scavenging assay. The results, as can be found from Figure 6 and Table 2, indicate that the extract is more effective hydroxyl radical scavenger than standard mannitol. Similar physiological damage of the liposomes by $\mathrm{OH}^{*}$ radical induces lipid peroxidation via pathways involving iron and singlet oxygen by the Fenton reaction $\left(\mathrm{H}_{2} \mathrm{O}_{2}+\mathrm{Fe}^{2+}=\right.$ $\mathrm{Fe}^{3+}+\mathrm{OH}^{-}+\mathrm{OH}^{*}$ ) [29]. Lipo-peroxidation inhibitory effect of the extract is reflected in Figure 7 in a dose dependent manner, similarly like standard trolox, although the calculated $\mathrm{IC}_{50}$ values for the extract in comparison to that of trolox (Table 2) indicate that the sample is not as potent inhibitor of lipid peroxidation as the reference compound.
Superoxide anion radical is well known as an initiator radical in the formation of other reactive oxygen-species, such as hydrogen peroxide or singlet oxygen in living systems [30]. The decrease in absorbance at $560 \mathrm{~nm}$ with the extract and the reference compound quercetin indicate their abilities to quench superoxide radicals in the reaction mixture (Figure 8 ). The $\mathrm{IC}_{50}$ values of the same (Table 2) indicate that the extract is more potent superoxide radical scavenger than standard compound quercetin.

Hydrogen peroxide, a weak oxidizing agent, can cross biological membranes and involve in the generation of hydroxyl radicals. This property has placed hydrogen peroxide in a more prominent role to initiate cytotoxicity than its chemical reactivity. Thus removing $\mathrm{H}_{2} \mathrm{O}_{2}$ is very important for the protection of living systems [31]. The plot of the scavenging activities in a concentrationdependent manner of the extract compared to standard sodium pyruvate (Figure 9) shows that the former is a mediocre scavenger of $\mathrm{H}_{2} \mathrm{O}_{2}$, as is also reflected from their respective $\mathrm{IC}_{50}$ values (Table 2). Scavenging of $\mathrm{H}_{2} \mathrm{O}_{2}$ by extracts may be attributed to their polyphenolics, which can donate electrons to $\mathrm{H}_{2} \mathrm{O}_{2}$, thus neutralizing it to water [32].

Nitric oxide is well known to have an important role in various inflammatory processes. The toxicity of NO increases greatly when it reacts with superoxide radical, forming the highly reactive peroxynitrite anion $\left(\mathrm{ONOO}^{-}\right)$ [33]. The extract inhibits the nitrite formation by directly competing with oxygen in the reaction with nitric oxide. The results (Figure 10 and Table 2) show that ETME has been found to be efficient in scavenging nitric oxide in a dose dependent manner, although not as potent as standard curcumin. Protonated peroxynitrite $\left(\mathrm{ONOO}^{-}\right)$ forms highly reactive peroxynitrous acid $(\mathrm{ONOOH})$ and

Table 2 Comparison of the antioxidant and free radical scavenging capacities of $70 \%$ methanol extract of $E$. tuba and standard reference compounds

\begin{tabular}{|c|c|c|c|}
\hline Name of assay & ETME & Standard & Values of standard compounds \\
\hline TEAC Values & $0.202 \pm 0.001$ & - & - \\
\hline \multicolumn{4}{|c|}{${ }^{*} \mid C_{50}$ values of the extracts for free radical scavenging capacity for } \\
\hline DPPH & $146.07 \pm 1.80$ & Ascorbic acid & $5.29 \pm 0.28^{* * *}$ \\
\hline Hydroxyl radical $\left(\mathrm{OH}^{\circ}\right)$ scavenging & $41.89 \pm 0.41$ & Mannitol & $571.45 \pm 20.12^{* * *}$ \\
\hline Lipid peroxidation & $202.49 \pm 33.32$ & Trolox & $6.76 \pm 0.17^{* * *}$ \\
\hline Superoxide anion $\left(\mathrm{O}_{2}^{\cdot-}\right)$ scavenging & $5.83 \pm 0.07$ & Quercetin & $42.06 \pm 1.35^{* * *}$ \\
\hline Hydrogen peroxide $\left(\mathrm{H}_{2} \mathrm{O}_{2}\right)$ scavenging & $47.34 \pm 5.05$ & Sodium pyruvate & $3.24 \pm 0.30^{* * *}$ \\
\hline Nitric oxide radical (NO) scavenging & $278.46 \pm 15.02$ & Curcumin & $90.82 \pm 4.75^{* * *}$ \\
\hline Peroxynitrite (ONOO$\left.{ }^{-}\right)$scavenging & $2.821 \pm 1.69$ & Gallic acid & $0.876 \pm 0.57^{* * *}$ \\
\hline Singlet oxygen $\left({ }^{1} \mathrm{O}_{2}\right)$ scavenging & $0.879 \pm 0.29$ & Lipoic acid & $0.046 \pm 0.01^{* * *}$ \\
\hline Hypochlorous acid (HOCl) scavenging & $223.25 \pm 4.19$ & Ascorbic acid & $235.96 \pm 5.75^{* *}$ \\
\hline
\end{tabular}

${ }^{*} \mathrm{I} \mathrm{C}_{50}$ Values are in $\mu \mathrm{g} / \mathrm{ml}$ (except for Hydrogen peroxide, Peroxynitrite and Singlet oxygen scavenging assay where values are expressed in mg/ml). Each value represents mean \pm S.D. $(n=6)$. ${ }^{* *} p<0.001,{ }^{* *} p<0.01$ vs ETME. 

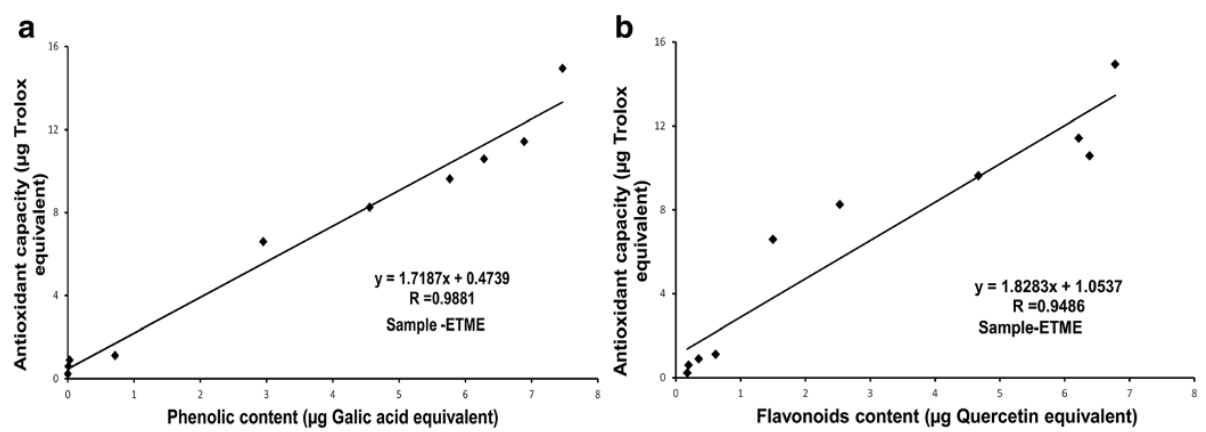

Figure 4 Correlation of total antioxidant activity with phenolic and flavonoid contents. The relationship between (a) total phenolic content or (b) total flavonoid content in the extract and their antioxidant capacity. The correlation analyses were described as linear correlation coefficient (R).

generate excess $\mathrm{ONOO}^{-}$which leads to oxidative damage and tissue injury [27]. When different amounts of extract and standard reference compound gallic acid were added to the reaction mixture, $\mathrm{ONOO}^{-}$-mediated oxidising activity was inhibited markedly in a concentration-dependent manner, as shown in Figure 11 even not as well as the reference compound (Table 2).

Singlet oxygen is a high energy form of oxygen generally produced in biological systems by photoexcitation upon exposure to UV radiation or by chemiexcitation. It induces hyper-oxidation, oxygen cytotoxicity and decreases the antioxidant activity [34]. Figure 12 and the $\mathrm{IC}_{50}$ values from Table 2 illustrate the ability of scavenging singlet oxygen by the extract and standard lipoic acid.

$\mathrm{HOCl}$ is produced in vivo by the oxidation of $\mathrm{Cl}^{-}$ions catalysed by neutrophil-derived myeloperoxidase in the presence of $\mathrm{H}_{2} \mathrm{O}_{2}$, at sites of inflammation [35]. $\mathrm{HOCl}$ damages and induce target cell lysis, caused by sulfhydryl oxidation in plasma membrane proteins and inactivates antioxidant enzymes like catalase [36]. Thus, this

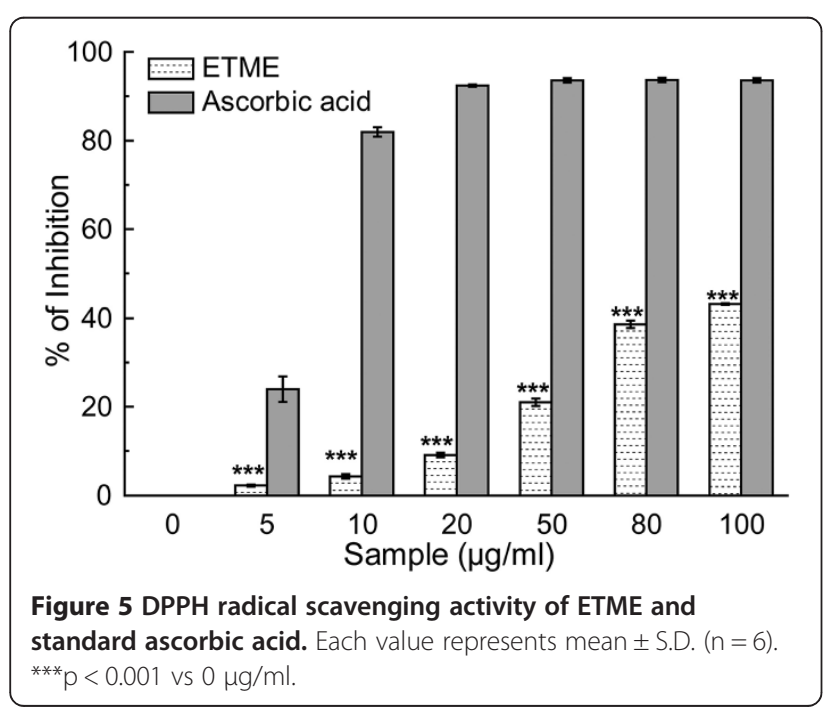

extract may have protective effects in vivo during inflammation processes. Dose-dependent hypochlorous acid scavenging activity of ETME and standard ascorbic acid was found in this study as shown in Figure 13 and the $\mathrm{IC}_{50}$ values (Table 2 ).

\section{Conclusions}

Literature survey revealed that Ginkgo biloba, Curcuma longa, Spondias pinnata and several other plants were confirmed as a source for potent antioxidant phytochemicals due to scavenging activity of the similar free radicals $[27,37,38]$ as ETME. Considering the results obtained, it may be anticipated that $70 \%$ methanol extract of $E$. tuba, which contains large amounts of bioactive phytocompounds, exhibits high antioxidant and free radical scavenging activities with high reducing power capacity. Scavenging abilities of the extract was observed mainly on superoxide, hydroxyl and hypochlorous acid radicals. These in vitro assays indicate that this algal extract is a significant source of natural antioxidant, which

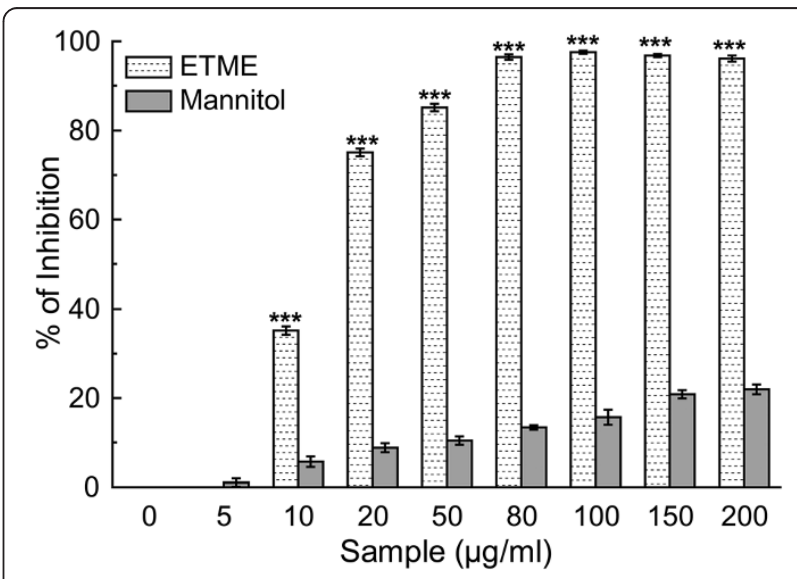

Figure 6 Hydroxyl radical scavenging activity of the ETME and the reference compound mannitol. The data represent the percentage of inhibition of deoxyribose degradation. The results are mean \pm S.D. $(n=6) .{ }^{* *} \mathrm{p}<0.001$ vs $0 \mu \mathrm{g} / \mathrm{ml}$. 


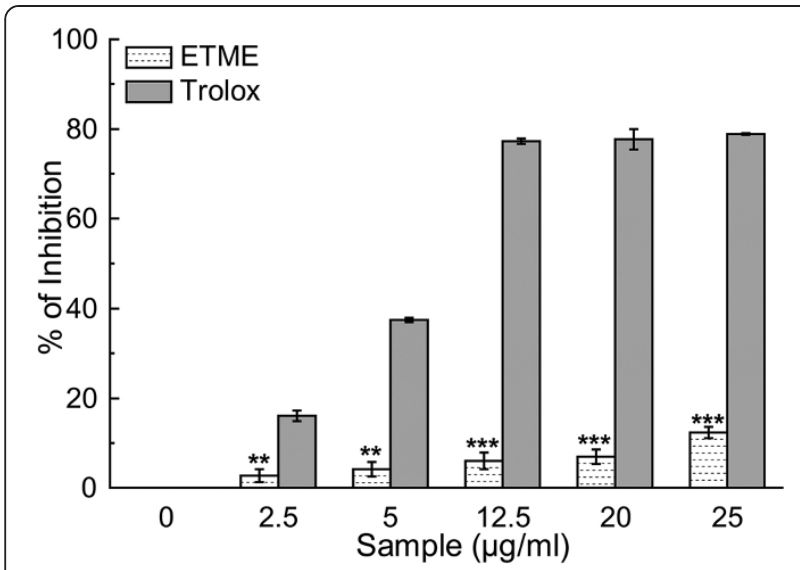

Figure 7 The inhibitory effect of ETME and standard trolox on lipid peroxidation. This phenomenon is shown as percentage inhibition of peroxidation of lipids from mice brain homogenate. The results are mean \pm S.D. $(n=6) .{ }^{* *} p<0.01$ and ${ }^{* * *} p<0.001$ vs $0 \mu \mathrm{g} / \mathrm{ml}$.

might be helpful in preventing the progress of various oxidative stresses which is also beneficial in prevention of "various other human diseases" [39]. However, the in vivo antioxidant activity of this extract needs to be assessed prior to clinical use.

\section{Methods}

\section{Chemicals}

2,2' -azinobis-(3-ethylbenzothiazoline-6-sulfonic acid) (ABTS) was procured from Roche diagnostics, Mannheim, Germany, and 6-hydroxy-2,5,7,8-tetramethylchroman-2carboxylic acid (Trolox) was obtained from Fluka, Buchs, Switzerland. Potassium persulfate $\left(\mathrm{K}_{2} \mathrm{~S}_{2} \mathrm{O}_{8}\right), 2$-deoxy-2-ribose, ethylene diammine tetraacetic acid (EDTA), ascorbic acid, trichloroacetic acid (TCA), mannitol, nitro blue

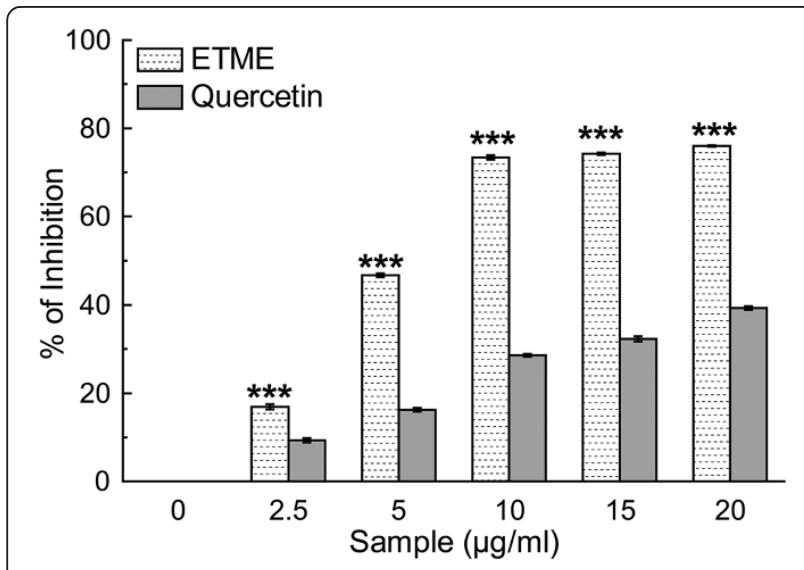

Figure 8 Scavenging effect of $E$. tuba extract and standard quercetin on superoxide radical. The data represents the percentage of superoxide radical inhibition. All data are expressed as mean \pm S.D. $(n=6) .{ }^{* *} \mathrm{p}<0.001$ vs $0 \mu \mathrm{g} / \mathrm{ml}$.

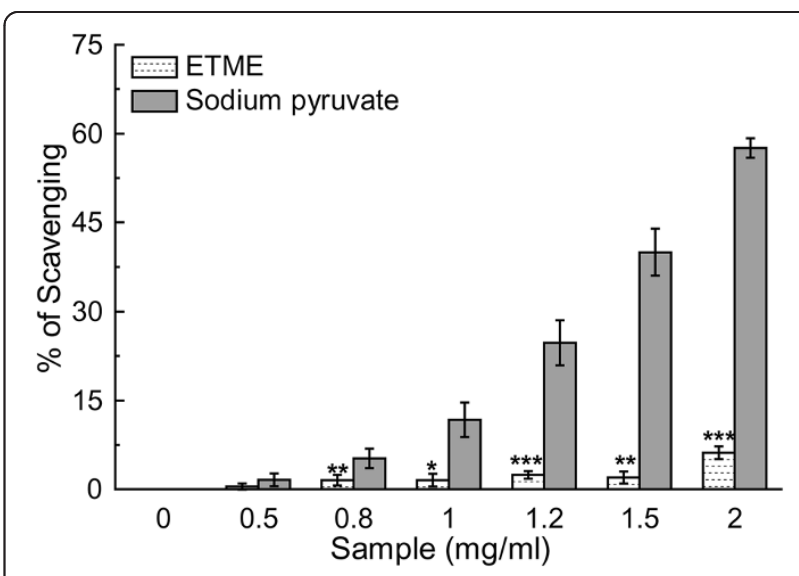

Figure $9 \mathrm{H}_{2} \mathrm{O}_{2}$ scavenging assay of ETME and sodium pyruvate. Values are expressed as mean \pm S.D. $(n=6) .{ }^{*} p<0.05,{ }^{* *} p<0.01$ and ${ }^{* * *} \mathrm{p}<0.001$ vs $0 \mathrm{mg} / \mathrm{ml}$.

tetrazolium (NBT), reduced nicotinamide adenine dinucleotide (NADH), phenazine methosulfate (PMS), sodium nitroprusside (SNP), 1,10-phenanthroline, sulphanilamide, $\mathrm{N}$-(1-Naphthyl)ethylenediamine dihydrochloride (NED), L-histidine, lipoic acid, sodium pyruvate, quercetin and ferrozine were obtained from Sisco Research Laboratories Pvt. Ltd, Mumbai, India. Hydrogen peroxide, potassium hexacyanoferrate, Folin-ciocalteu reagent, sodium carbonate, mercuric chloride, potassium iodide, anthrone, vanillin, thiourea, 2,4-dinitrophenylhydrazine, sodium hypochlorite, aluminium chloride, xylenol orange, butylated hydroxyltoluene (BHT) and N,N- dimethyl-4-nitrosoaniline were procured from Merck, Mumbai, India. 1,1-diphenyl-2-picrylhydrazyl (DPPH), gallic acid were obtained from MP Biomedicals, France. Catalase and sodium bicarbonate were obtained from HiMedia Laboratories Pvt. Ltd, Mumbai, India. Evans Blue was purchased

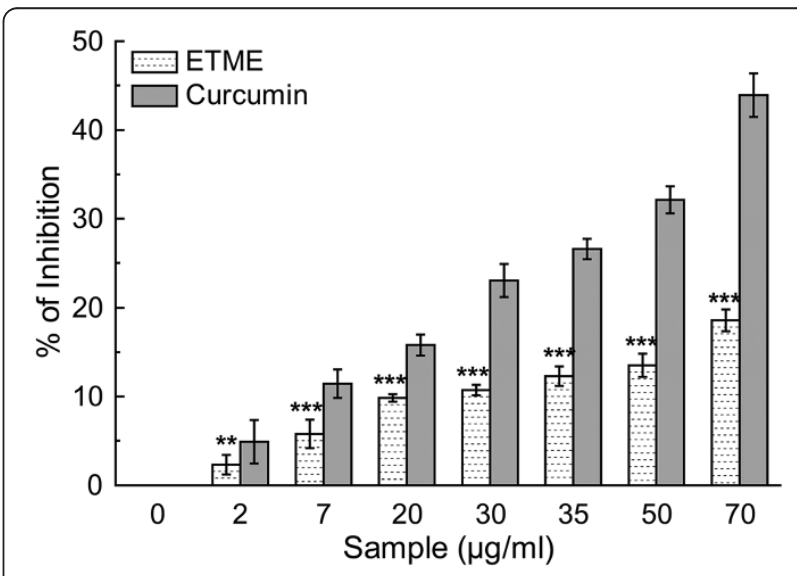

Figure 10 The nitric oxide radical scavenging activity of $E$. tuba extract and standard curcumin. The data represents the $\%$ of nitric oxide inhibition. Each value represents mean \pm S.D. $(n=6) .{ }^{* *} p<0.001$ vs $0 \mu \mathrm{g} / \mathrm{ml}$. 


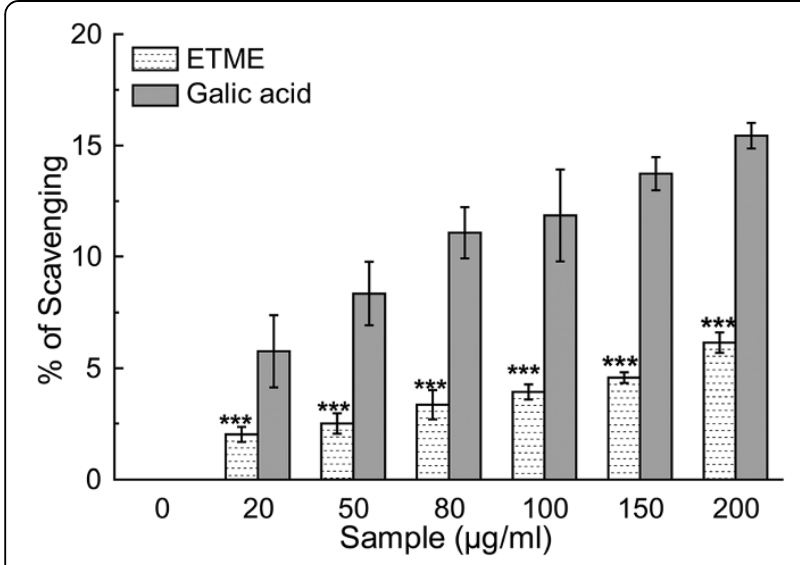

Figure 11 Peroxynitrite anion scavenging assay of E. tuba extract and the standard gallic acid. Value represents mean \pm S.D. $(n=6) .{ }^{* * *} p<0.001$ vs $0 \mu \mathrm{g} / \mathrm{ml}$.

from BDH, England. D-glucose was procured from Qualigens Fine Chemicals, Mumbai. Diethylenetriaminepentaacetic acid (DTPA) was obtained from Spectrochem Pvt. Ltd, Mumbai, India. Thiobarbituric acid (TBA) was obtained from Loba Chemie, Mumbai, India.

\section{Algal characterisation and extract preparation}

Algal samples were collected with the help of a plankton net made of bolting silk cloth from different ponds of 'Cachar' district of the state of Assam, India, situated at N24 $41^{\prime} 23.64^{\prime \prime}$ E92 $45^{\prime} 04.42^{\prime \prime}$ and 36.5 MSL. The samples were preserved in formalin (4\%) for identification and observed under the light microscope following standard keys [40,41]. Simultaneously, fresh algal samples were thoroughly cleaned in sterile distilled water for three times to remove extraneous materials adhering to

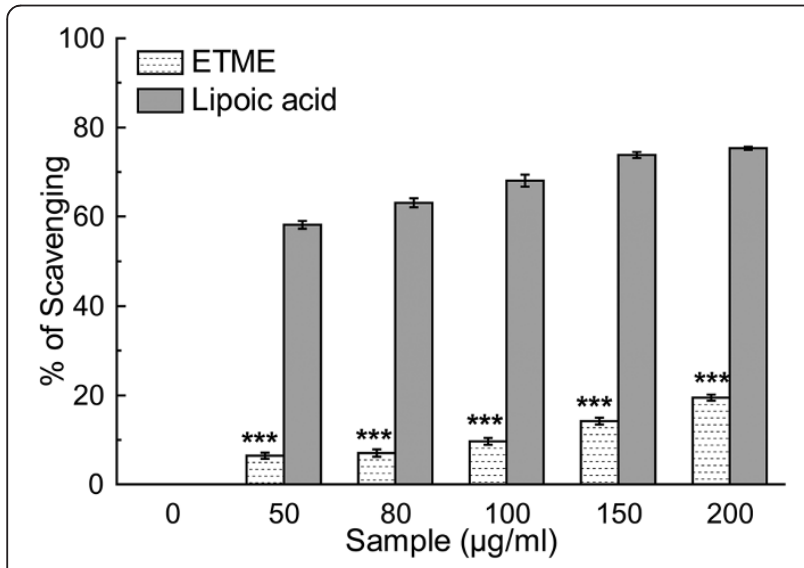

Figure 12 Effect of ETME and standard lipoic acid on the scavenging of singlet oxygen. The results are mean \pm S.D. $(n=6)$. *** $p<0.001$ vs $0 \mu \mathrm{g} / \mathrm{ml}$.

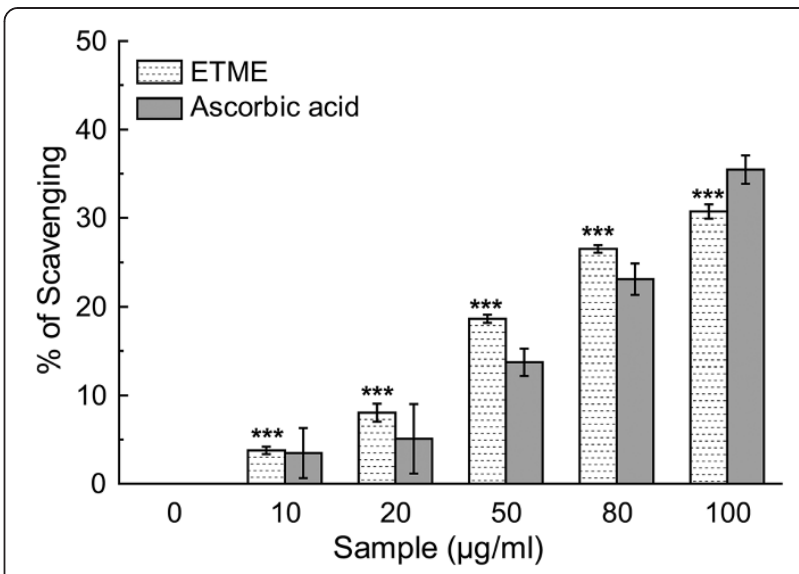

Figure 13 Hypochlorous acid scavenging activity of $E$. tuba extract and standard ascorbic acid. All data are expressed as mean \pm S.D. $(n=6) .{ }^{* * *} p<0.001$ vs $0 \mu \mathrm{g} / \mathrm{ml}$. it and finally centrifuged at $1000 \times g$ using macro rotor to remove contaminated bacteria [17]. The collected pellet as biomass of euglena was dried at ambient temperature for seven days, finely powdered for extraction purpose. The powder (100 g) was mixed with $1000 \mathrm{ml}$ methanol:water (7:3) using a magnetic stirrer for $15 \mathrm{~h}$ and then centrifuged at $2850 \times g$ for obtaining the supernatant. The process was repeated by mixing the precipitated pellet with $1000 \mathrm{ml}$ fresh solvent. The supernatants from both the phases were mixed and concentrated under reduced pressure in a rotary evaporator, followed by lyophilisation. The lyophilized 70\% methanol extract of E. tuba, designated as ETME was kept at $-20^{\circ} \mathrm{C}$ for future use. A freshly prepared aqueous solution of ETME of different concentration was used for various experiments.

\section{Animals}

Adult male Swiss Albino mice (Mus musculus) weighing 20-25 g, required for lipid peroxidation inhibition study were kept as 4 mice/cage at $25 \pm 2^{\circ} \mathrm{C}$ and $60 \pm 5 \%$ humidity and normal photo cycle (12 h dark/12 h light), and supplied with ad libitum laboratory diet and water. The Institutional Animal Ethics Committee of the Institute (Registration number: 95/1999/CPCSEA) approved use of the animals for experimentation.

\section{Phytochemical analysis \\ Qualitative analysis}

Phytochemical analysis of ETME was carried out using standard qualitative methods by Harborne and Baxter [42] and Kokate et al. [43]. The components analysed for phytochemicals were alkaloids, carbohydrates, flavonoids, glycosides, phenols, saponins, tannins, terpenoids, anthraquinones and triterpenoids. 


\section{Quantitative phytochemical analysis Total phenolic content}

The total phenolic content present in ETME was determined using Folin-Ciocalteu (FC) method done earlier [27]. Briefly, $0.1 \mathrm{ml}$ extract was mixed with $0.75 \mathrm{ml}$ FC reagent (previously diluted 1000-fold with distilled water), followed by the addition of $0.06 \% \mathrm{Na}_{2} \mathrm{CO}_{3}(0.75 \mathrm{ml})$ solution. After incubation at $22^{\circ} \mathrm{C}$ for $90 \mathrm{~min}$, the absorbance was taken at $725 \mathrm{~nm}$. All tests were performed six times. The phenolic content was evaluated from a gallic acid standard curve.

\section{Total flavonoid content}

Total flavonoid content was determined according to Hazra et al. [27]. $0.1 \mathrm{ml}$ extract was added to $0.03 \mathrm{ml}$ $5 \% \mathrm{NaNO}_{2}$. After incubation for $5 \mathrm{~min}$ at $25^{\circ} \mathrm{C}, \mathrm{AlCl}_{3}$ (0.03 $\mathrm{ml}, 10 \%)$ was added, followed by $0.2 \mathrm{ml} 1 \mathrm{mM}$ $\mathrm{NaOH}$. Finally, the reaction mixture was diluted to $1 \mathrm{ml}$ with water and the absorbance was measured at $510 \mathrm{~nm}$. The flavonoid content from six repetitions was calculated from a quercetin standard curve.

\section{Quantification of carbohydrate content}

Carbohydrate content of the extract was quantified following previously performed method [44]. Briefly, $100 \mathrm{mg}$ of ETME was hydrolysed with $5 \mathrm{ml}$ of $2.5 \mathrm{~N} \mathrm{HCl}$. The mixture was diluted to $100 \mathrm{ml}$ with distilled water and centrifuged. $0.25 \mathrm{ml}$ supernatant was made up to $0.5 \mathrm{ml}$ using distilled water and mixed with $4 \mathrm{ml}$ anthrone reagent and was incubated at $95^{\circ} \mathrm{C}$ for $8 \mathrm{~min}$. After incubation, absorbance of the resultant dark green coloured solution was measured at $630 \mathrm{~nm}$. All tests were performed six times. The carbohydrate content was evaluated from a glucose standard curve.

\section{Quantification of alkaloid content}

Quantification of alkaloid content of ETME was done using previously implemented protocol [45]. To $1 \mathrm{ml}$ of extract $(1 \mathrm{mg} / \mathrm{ml})$ in water $0.1 \mathrm{ml}$ of $\mathrm{FeCl}_{3}(2.5 \mathrm{mM}$ $\mathrm{FeCl}_{3}$ in $0.5 \mathrm{M} \mathrm{HCl}$ ) was added followed by addition of $0.1 \mathrm{ml} \mathrm{1,10-phenanthroline.} \mathrm{After} \mathrm{incubation} \mathrm{for} 30 \mathrm{~min}$ at $70^{\circ} \mathrm{C}$ the absorbance was measured at $500 \mathrm{~nm}$. All tests were performed six times. The alkaloid content was quantified from the reserpine standard graph.

\section{Quantification of ascorbic acid content}

Ascorbic acid content quantification was accomplished according to the previously elucidated technique [45]. In brief, $1 \mathrm{ml}$ aliquots of ETME $(1 \mathrm{mg} / \mathrm{ml})$ in water were mixed with $1 \mathrm{ml}$ of '2,4-dinitro-phenylhydrazine reagent' and was incubated at $95^{\circ} \mathrm{C}$ for $15 \mathrm{~min}$. After incubation, $5 \mathrm{ml}$ of $85 \% \mathrm{H}_{2} \mathrm{SO}_{4}$ was added drop wise to the reaction mixture in ice cold condition. After $30 \mathrm{~min}$, the absorbance was measured at $520 \mathrm{~nm}$. All tests were performed six times. The ascorbic acid content was expressed as L-ascorbic acid equivalent.

\section{Quantification of Tannin content}

This assay was performed according to the technique followed earlier [44]. Briefly, $0.1 \mathrm{ml}$ aliquot of ETME $(1 \mathrm{mg} / \mathrm{ml})$ was mixed with the $0.5 \mathrm{ml}$ vanillin hydrochloride reagent and incubated for $20 \mathrm{~min}$ at room temperature. The absorbance of the resulting magenta-pink colour was measured at $500 \mathrm{~nm}$. All tests were performed six times. The tannin content was evaluated from a catechin standard graph.

\section{HPLC standardisation of the extract}

For HPLC analysis, stock solutions $(10 \mu \mathrm{g} / \mathrm{ml})$ were prepared in the mobile phase for the sample and different standard phytocompounds. Samples were then filtered through $0.45 \mu \mathrm{m}$ polytetrafluoroethylene (PTFE) filter (Millipore) to remove any particulate matter. Analysis was performed using a HPLC-Prominence System RF10AXL (Shimadzu Corp., Japan) equipped with degasser (DGU$20 \mathrm{~A}_{5}$ ), quaternary pump (LC-20AT), auto-sampler (SIL-20A) and detectors of Reflective Index (RID-10A), Fluorescence (RF-10AXL) and Diode Array (SPD-M20A). The injection volume used was $20 \mu \mathrm{l}$ and the sample and standards were analyzed in triplicates. Gradient elution consecutive mobile phases of acetonitrile and $0.5 \mathrm{mM}$ ammonium acetate in water, at a flow rate of $1 \mathrm{ml} / \mathrm{min}$ for 80 min through the column (ZIC ${ }^{\oplus}$-HILIC) that was maintained at $25^{\circ} \mathrm{C}$. The detection was carried out at $254 \mathrm{~nm}$.

\section{In vitro antioxidant and free radical scavenging assays Total antioxidant activity}

Antioxidant capacity of the extract $(0.05-10 \mathrm{mg} / \mathrm{ml})$ were evaluated by $\mathrm{ABTS}^{\circ+}$ radical cation decolourisation assay in comparison to trolox standard [27]. The absorbance of the $\mathrm{ABTS}^{*+}$ solution was equilibrated to $0.70( \pm 0.02)$ by diluting with water at room temperature, then $1 \mathrm{ml}$ $\mathrm{ABTS}^{\bullet+}$ solution was mixed with $10 \mu \mathrm{l}$ of the test sample and the absorbance was measured at $734 \mathrm{~nm}$ after $6 \mathrm{~min}$. The experiment was repeated six times. The percentage inhibition of absorbance was calculated and plotted as a function of the concentration of standard and sample to determine the trolox equivalent antioxidant concentration (TEAC), calculated as the ratio of the gradients of the plots for the sample to trolox.

\section{Measurement of reducing power}

The $\mathrm{Fe}^{3+}$-reducing power of the extract was determined by a standard method [27]. Different concentrations $(0-1.0 \mathrm{mg} / \mathrm{ml})$ of the extract were mixed with equivolume $0.2 \mathrm{M}$ phosphate buffer ( $\mathrm{pH} 6.6$ ) and $0.1 \%$ potassium hexacyanoferrate, followed by incubation for $20 \mathrm{~min}$ at $50^{\circ} \mathrm{C}$. After incubation, the reaction was terminated with $0.5 \mathrm{ml}$ 
10\% TCA. Then, $1 \mathrm{ml}$ reaction mixture was diluted with $1 \mathrm{ml}$ distilled water followed by the addition of $0.1 \mathrm{ml} \mathrm{FeCl}$ solution $(0.01 \%)$. The reaction mixture was left for $10 \mathrm{~min}$ at room temperature and the absorbance was measured at $700 \mathrm{~nm}$ against an appropriate blank solution. All tests were performed six times. Ascorbic acid was used as a standard.

\section{DPPH radical scavenging assay}

The complementary study for the antioxidant capacity of the extract was confirmed by the DPPH $(1,1$ diphenyl-2-picrylhydrazyl) scavenging assay according to Mahakunakorn et al. [46], with slight modification. Different concentrations $(0-100 \mu \mathrm{g} / \mathrm{ml})$ of the extract and the standard ascorbic acid were mixed with equal volume of ethanol. Then $50 \mu \mathrm{l}$ of DPPH solution $(1 \mathrm{mM})$ was added into the mixture and stirred thoroughly. The resulting solution was kept standing for 2 min before the OD was measured at $517 \mathrm{~nm}$. The measurement was repeated with six sets. The percentage of scavenging was calculated from the values of the control and the test samples.

\section{Hydroxyl radical scavenging assay}

The hydroxyl radical scavenging assay was performed using a standard protocol [27], based on quantification of the degradation product of 2-deoxyribose condensed with TBA. Hydroxyl radical was generated by the $\mathrm{Fe}^{3}$ ${ }^{+}$-ascorbate-EDTA- $\mathrm{H}_{2} \mathrm{O}_{2}$ system (the Fenton reaction). In a final volume of $1 \mathrm{ml}$, various concentrations of the test sample or reference compound was mixed with 2deoxy-2-ribose (2.8 mM); $\mathrm{KH}_{2} \mathrm{PO}_{4}-\mathrm{KOH}$ buffer $(20 \mathrm{mM}$, pH 7.4); $\mathrm{FeCl}_{3}(100 \mu \mathrm{M}) ;$ EDTA $(100 \mu \mathrm{M}) ; \mathrm{H}_{2} \mathrm{O}_{2}$ $(1.0 \mathrm{mM})$; ascorbic acid $(100 \mu \mathrm{M})$ and incubated for $1 \mathrm{~h}$ at $37^{\circ} \mathrm{C} .0 .5 \mathrm{ml}$ of the reaction mixture was added to $2.8 \%$ TCA, followed by $1 \% \mathrm{TBA}$ and incubated at $90^{\circ} \mathrm{C}$ to develop the colour of TBARS (Thiobarbituric acid reactive substance). Absorbance was measured at $532 \mathrm{~nm}$ against an appropriate blank solution. All tests were performed six times. Mannitol, a classical $\mathrm{OH}^{*}$ scavenger, was used as a positive control. Percentage inhibition was evaluated by comparing the test and blank solutions.

\section{Inhibition of lipid peroxidation}

The ability of ETME to inhibit lipid peroxidation was evaluated by the method of Sarkar et al. [47]. Brain homogenate was prepared by centrifuging Swiss Albino mice brain with $50 \mathrm{mM}$ phosphate buffer and $120 \mathrm{mM} \mathrm{KCl}$. An aliquot of the supernatant homogenate was mixed with various concentrations of the extract $(2.5-25 \mu \mathrm{g} / \mathrm{ml})$ along with the standard Trolox, followed by addition of $0.1 \mathrm{mM} \mathrm{FeSO}_{4}$ and $0.1 \mathrm{mM}$ ascorbic acid and incubated for $1 \mathrm{~h}$ at $37^{\circ} \mathrm{C}$ to generate TBARS. After stopping the reaction with TCA, TBA was added and the absorbance of the supernatant was taken at $532 \mathrm{~nm}$. All tests were repeated six times.

\section{Superoxide radical scavenging assay}

This activity was measured by the reduction of NBT according to an earlier method [48]. The $1 \mathrm{ml}$ reaction mixture contained phosphate buffer $(20 \mathrm{mM}, \mathrm{pH} 7.4)$, NADH $(73 \mu \mathrm{M})$, NBT $(50 \mu \mathrm{M})$, PMS $(15 \mu \mathrm{M})$ and various concentrations $(0-20 \mu \mathrm{g} / \mathrm{ml})$ of sample and standard quercetin solution. After incubation for $5 \mathrm{~min}$ at ambient temperature $\left(20-25^{\circ} \mathrm{C}\right)$, quantity of generated formazan was measured at $562 \mathrm{~nm}$ against an appropriate blank. All tests were performed six times.

\section{Hydrogen peroxide scavenging assay}

FOX-reagent was used to evaluate the $\mathrm{H}_{2} \mathrm{O}_{2}$ scavenging property of ETME with reference to sodium pyruvate [27]. An aliquot of $50 \mathrm{mM} \mathrm{H}_{2} \mathrm{O}_{2}$ and various concentrations $(0-2 \mathrm{mg} / \mathrm{ml})$ of samples were mixed $(1: 1 \mathrm{v} / \mathrm{v})$ and incubated for $30 \mathrm{~min}$ at room temperature. $90 \mu \mathrm{l}$ of the incubated reaction mixture was mixed with $10 \mu \mathrm{l}$ HPLCgrade methanol followed by $0.9 \mathrm{ml}$ FOX reagent and incubated at ambient temperature for $30 \mathrm{~min}$. The absorbance of the ferric-xylenol orange complex was measured at $560 \mathrm{~nm}$. All tests were carried out six times.

\section{Nitric oxide radical scavenging assay}

Nitric oxide generated from the SNP aqueous solution at physiological $\mathrm{pH}$, interacts with oxygen to produce nitrite ions which were measured by Griess Illosvoy reaction [27]. The reaction mixture $(3 \mathrm{ml})$ contained $10 \mathrm{mM}$ SNP, phosphate buffered saline ( $\mathrm{pH}$ 7.4) and various doses of ETME $(0-70 \mu \mathrm{g} / \mathrm{ml})$. Curcumin was used as a standard compound. After incubation for $150 \mathrm{~min}$ at $25^{\circ} \mathrm{C}, 1 \mathrm{ml}$ sulfanilamide $(0.33 \%$ in $20 \%$ glacial acetic acid) was added to $0.5 \mathrm{ml}$ of the incubated solution and again after $5 \mathrm{~min}$, $1 \mathrm{ml} \mathrm{NED}(0.1 \% \mathrm{w} / \mathrm{v})$ was mixed and incubated for $30 \mathrm{~min}$ at $25^{\circ} \mathrm{C}$. The pink chromophore generated was measured spectrophotometrically at $540 \mathrm{~nm}$ against a blank sample. All tests were performed six times.

\section{Peroxynitrite radical scavenging assay}

Peroxynitrite $\left(\mathrm{ONOO}^{-}\right)$was synthesized $12 \mathrm{~h}$ before the experiment as described by Beckman et al. [49]. The peroxynitrite scavenging activity of the extract and reference gallic acid was measured by Evans' blue bleaching assay according to a standard method [27]. In a $1 \mathrm{ml}$ reaction mixture contained $50 \mathrm{mM}$ phosphate buffer ( $\mathrm{pH} 7.4)$, $0.1 \mathrm{mM}$ DTPA, $90 \mathrm{mM} \mathrm{NaCl}, 5 \mathrm{mM} \mathrm{KCl}, 12.5 \mu \mathrm{M}$ Evans Blue, various doses ETME $(0-200 \mu \mathrm{g} / \mathrm{ml})$ and $1 \mathrm{mM}$ peroxynitrite. After incubation at $25^{\circ} \mathrm{C}$ for $30 \mathrm{~min}$ the absorbance was measured at $611 \mathrm{~nm}$. The percentage scavenging of $\mathrm{ONOO}^{-}$was calculated by comparing the results of the test and blank samples. All tests were performed six times. 


\section{Singlet oxygen radical scavenging assay}

The production of singlet oxygen $\left({ }^{1} \mathrm{O}_{2}\right)$ was determined by monitoring $\mathrm{N}, \mathrm{N}$-dimethyl-4-nitrosoaniline (RNO) bleaching, using a previously reported protocol [27]. The final reaction mixture $(2 \mathrm{ml})$ contained $45 \mathrm{mM}$ phosphate buffer (pH 7.1), $50 \mathrm{mM} \mathrm{NaOCl}, 50 \mathrm{mM} \mathrm{H}_{2} \mathrm{O}_{2}, 50 \mathrm{mM}$ histidine, $10 \mu \mathrm{M}$ RNO and various concentrations $(0-200 \mu \mathrm{g} / \mathrm{ml})$ of sample. After incubation at $30^{\circ} \mathrm{C}$ for $40 \mathrm{~min}$ the decrease in RNO absorbance was measured at $440 \mathrm{~nm}$. The scavenging activity of sample was compared with that of a reference compound, lipoic acid. All tests were performed six times.

\section{Hypochlorous acid scavenging assay}

According to a standard protocol described by Hazra et al. [27] the $1 \mathrm{ml}$ reaction mixture contained $50 \mathrm{mM}$ phosphate buffer ( $\mathrm{pH} 6.8)$, catalase $(7.2 \mu \mathrm{M})$, freshly prepared $\mathrm{HOCl}(8.4 \mathrm{mM})$ and increasing concentrations $(0-100 \mu \mathrm{g} / \mathrm{ml})$ of ETME. The assay mixture was incubated at $25^{\circ} \mathrm{C}$ for $20 \mathrm{~min}$ and the scavenging activity of the extract and the standard ascorbic acid was evaluated by measuring the decrease in absorbance of catalase at $404 \mathrm{~nm}$.

\section{Statistical analysis}

All data are given as the mean $\pm \mathrm{SD}$ of six measurements. Statistical analysis was performed using KyPlot version 2.0 beta 15 (32 bit). The $\mathrm{IC}_{50}$ values were calculated by the formula $\mathrm{Y}=100 * \mathrm{~A} 1 /(\mathrm{X}+\mathrm{A} 1)$, where $\mathrm{A} 1=$ $\mathrm{IC}_{50}, \mathrm{Y}=$ response $(\mathrm{Y}=100 \%$ when $\mathrm{X}=0), \mathrm{X}=$ inhibitory concentration. The $\mathrm{IC}_{50}$ values were compared by paired ' $t$ ' tests. $\mathrm{P}<0.05$ was considered significant. All the graphics were finally processed using Adobe Photoshop v.7.

\section{Competing interests}

The authors declare that they have no competing interests.

\section{Authors' contributions}

Conceived and designed the experiments: NM. Performed the experiments: DC, NBG, SP. Analysed the data: DC, NBG, RS. Contributed reagents/materials/ analysis tools: SD, JR. Wrote the paper: DC, RS, NM. All authors read and approved the final manuscript.

\section{Acknowledgements}

Shampa Deb is grateful to University Grants Commission (UGC), Government of India for fellowship. The authors would like to acknowledge Dr. Bibhabasu Hazra for critical reviewing of the manuscript. The authors would also like to thank Mr. Ranjit Kumar Das and Mr. Pradip Kumar Mallick for technical assistance in sample preparation and handling of lab wares and animals in experimental procedures.

\section{Author details}

${ }^{1}$ Division of Molecular Medicine, Bose Institute, P-1/12 CIT Scheme VIIM, Kolkata 700054, India. ${ }^{2}$ Department of Ecology and Environmental Science, Assam University, Silchar 788011, Assam, India.

Received: 17 January 2014 Accepted: 21 May 2014

Published: 4 June 2014

\section{References}

1. Khan MA: Euglenoid Red-bloom contributing to the Environmental Pollution of Dal Lake, Kashmir Himalaya. Environ Conserv 1993, 20:352-356

2. Abalde J, Fabregas J, Herrero C: $\beta$-Carotene, vitamin C, vitamin E content of the marine microalga Dunaliella tertiolecta cultured with different nitrogen source. Biores Technol 1991, 38:121-125.

3. Dillon JC, Phan PA: Spirulina source of protein in human nutrition. Bull Inst Oceanol 1993, 12:103-107.

4. Dudonne S, Vitrac S, Coutiere P, Woillez M, Merillon JM: Comparative study of antioxidant properties and total phenolic content of 30 plant extracts of industrial interest using DPPH, ABTS, FRAP, SOD and ORAC assays. J Agric Food Chem 2009, 57:1768-1774.

5. Barahona T, Chandía NP, Encinas MV, Matsuhiro B, Zúñiga EA: Antioxidant capacity of sulfated polysaccharides from seaweed: a kinetic approach. Food Hydrocoll 2011, 25:529-535.

6. Takeyama H, Kanamaru A, Yoshimo Y, Katuta H, Kawamura Y, Matsunaga T: Production of antioxidant vitamins, beta-carotene, vitamin $C$, and vitamin E, by two step culture of Euglena gracilis Z. Biotechnol Bioeng 1997, 53:185-190.

7. Percival M: Antioxidants. Clin Nutr 1998. Insight nut 031 1/96 rev. 10/98.

8. Hermans N, Cos P, Maes L, Bruyne TD, Berghe DV, Vlietinck AJ, Pieters L: Challenges and pitfalls in antioxidant research. Curr Med Chem 2007 14:417-430

9. Grice HP: Enhanced tumour development by butylated hydroxyanisole (BHA) from the prospective of effect on forestomach and oesophageal squamous epithelium. Food Chem Toxicol 1988, 26:717-723.

10. Wichi HC: Safety evaluation of butylated hydroxytoluene (BHT) in the liver, lung and gastrointestinal tract. Food Chem Toxicol 1986, 24:1127-1130.

11. Lobo V, Patil A, Phatak A, Chandra N: Free radicals, antioxidants and functional foods: Impact on human health. Pharmacogn Rev 2010, 4:118-126.

12. Hosmani SP: Seasonal changes in phytoplankton communities in a freshwater pond at Dharwar, Karnatak State, India. Phykos 1988, 27:82-87.

13. Wetzel RG: Limnology. Philadelphia, PA: Saunders College Publishing; 1983.

14. Munawar M: Limnological studies on the fresh water ponds of Hyderabad, India. The Biocenose-Distribution of unicellular and colonial phytoplankton in polluted and unpolluted environments. Hydrobiologia 1970, 35:127-162.

15. Xavier MB, Mainardes CSR, Pinto, Takino M: Euglena sanguinea, Ehrenberg bloom in a fish-breeding tank (Pindamonhangaba, Sao Paulo, Brazil). Archiv fur Hydrobiol 1991, 62:133-142.

16. Latham $\mathrm{H}$ : Temperature stress-induced bleaching of the coralline alga Corallina officinalis: a role for the enzyme bromoperoxidase. BiosC Horizon 2008, 1:104-113.

17. Das BK, Pradhan J, Pattnaik P, Samantaray BR, Samal SK: Production of antibacterials from the freshwater alga Euglena viridis (Ehren). World J Microbiol Biotechnol 2005, 21:45-50.

18. Kusmic C, Barsacchi R, Barsanti L, Gualtieri P, Passarelli V: Euglena gracilis as a source of the antioxidant vitamin E. Effects of culture conditions in the wild strain and in the natural mutant WZSL. J App/ Phycol 1999, 10:555-559.

19. Tomoko N, Takashi A, Hiromu T, Yuka I, Hiroko M, Munekazu I, Toshiyuki T, Tetsuro I, Fujio A, Iriya I, Tsutomu N, Kazuhito W: Antibacterial activity of extracts prepared from tropical and subtropical plants on methicillin resistant Staphylococcus aureus. J Health Sci 2002, 48:273-276.

20. Balch JF, Balch PA: Prescription for Nutritional Healing: A A Practical A-to-Z Reference to Drug-Free Remedies Using Vitamins, Minerals, Herbs \& Food Supplements. 5th edition. New York: Penguin Putnam Inc; 2000:267-270.

21. Jisika M, Ohigashi $H$, Nogaka H, Tada T, Hirota M: Bitter steroid glycosides, Vernon sides $A 1, A 2$, and $A 3$ and related $B 1$ from the possible medicinal plant Vernonia amygdalina used by wild Chimpanzees. Tetrahedron 1992, 48:625-630.

22. Panlasigui LN, Thompson LU, Juliano BO, Perez CM, Yiu SH, Greenberg GR: Rice varieties with similar amylose content differ in starch digestibility and glycemic response in humans. Am J Clin Nutr 1991, 54:871-877.

23. Acheson KJ, Schutz Y, Bessard T, Anantharaman K, Flatt JP, Jequier E: Glycogen storage capacity and de novo lipogenesis during massive carbohydrate overfeeding in man. Am J Clin Nutr 1989, 48:240-247. 
24. Adikwu E, Deo O: Hepatoprotective Effect of Vitamin C (Ascorbic Acid). Pharmacol Pharm 2013, 4:84-92.

25. Yildirim A, Mavi A, Kara AA: Determination of antioxidant and antimicrobial activities of Rumex crispus L. extracts. J Agric Food Chem 2001, 49:4083-4089.

26. Sudha G, Sangeetha PM, Indhu SR, Vadivukkarasi S: In vitro free radical scavenging activity of raw pepino fruit (Solanum muricatum aiton). Int J Curr Pharm 2011, 3:137-140.

27. Hazra B, Biswas S, Mandal N: Antioxidant and free radical scavenging activity of Spondias pinnata. BMC Complement Altern Med 2008, 8:63.

28. Halliwell B: Reactive oxygen species in living systems: source, biochemistry, and role in human disease. Am J Med 1991, 9:14S-22S

29. Vile GF, Tyrrell RM: UVA radiation-induced oxidative damage to lipids and proteins in vitro and in human skin fibroblasts is dependent on iron and singlet oxygen. Free Radic Biol Med 1995, 18:721-730.

30. Stief TW: The physiology and pharmacology of single oxygen. Med Hypotheses 2003, 60:567-572.

31. Van Wijk R, Van Wijk EP, Wiegant FA, Ives J: Free radicals and low-level photon emission in human pathogenesis: State of the art. Indian J Exp Biol 2008, 46:273-309.

32. Ebrahimzadeh MA, Nabavi SF, Nabavi SM: Antioxidant activities of methanol extract of Sambucus ebulus L. flower. Pak J Biol Sci 2009, 12:447-450

33. Huie RE, Padmaja S: The reaction of NO with superoxide. Free Radic Res Commun 1993, 18:195-199.

34. Kochevar El, Redmond WR: Photosnsitized production of singlet oxygen. Methods Enzymol 2003, 19:20-28.

35. Aruoma Ol, Halliwell B, Hoey BM, Butler J: The antioxidant action of $\mathrm{N}$-acetylcysteine: its reaction with hydrogen peroxide, hydroxyl radical, superoxide, and hypochlorous acid. Free Rad Biol Med 1989, 6:593-597.

36. Visioli F, Bellomo G, Galli C: Free radical-scavenging properties of olive oil polyphenols. Biochem Biophys Res Comm 1998, 247:60-64.

37. Maltas E, Yildiz S: Evaluation of Phytochemicals and Antioxidant Activity of Ginkgo biloba from Turkey. Pharmacologia 2012, 3:113-120.

38. Choi HY: Antioxidant Activity of Curcuma longa L. Novel Foodstuff. Mol Cell Toxicol 2009, 5:237-242.

39. Goodman M, Bostick RM, Kucuk O, Jones DP: Clinical trials of antioxidants as cancer prevention agents: past, present, and future. Free Rad Biol Med 2011, 51:1068-1084.

40. Prescott GW: Algae of the western great lakes area, Cranbrook Institute of Science. : 1951:393-830.

41. Leedale GF: Euglenoid flagellates. Englewood Cliffs NJ: Prentice Hall Inci 1967:27-28.

42. Harborne JB, Baxter H: Phytochemical dictionary: a handbook of bioactive compounds from plants. London: John St. Taylor \& Francis Ltd; 1995.

43. Kokate CK, Purohit AP, Gokhale SB: Test book of Pharmacognosy. Pune: Nirali Prakashan; 2003.

44. Chaudhuri D, Ghate NB, Sarkar R, Mandal N: Phytochemical analysis and evaluation of antioxidant and free radical scavenging activity of Withania somnifera root. Asian J Pharm Clin Res 2012, 5:193-199.

45. Ghate NB, Chaudhuri D, Mandal N: In vitro antioxidant and free radical scavenging assessment of Tinospora cordifolia stem with DNA protective potential. Int J Pharm Bio Sci 2013, 4:373-388.

46. Mahakunakorn P, Tohda M, Murakami Y, Matsumoto K, Watanabe H: Antioxidant and Free Radical-Scavenging Activity of Choto-san and Its Related Constituents. Biol Pharm Bull 2004, 27:38-46.

47. Sarkar R, Hazra B, Mandal S, Biswas S, Mandal N: Assessment of in vitro antioxidant and free radical scavenging activity of Cajanus cajan. J Complement Integrat Med 2009, 6:24.

48. Fontana M, Mosca L, Rosei MA: Interaction of enkephalines with oxyradicals. Biochem Pharmacol 2001, 61:1253-1257.

49. Beckman JS, Chen H, Ischiropulos H, Crow JP: Oxidative chemistry of peroxynitrite. Method Enzymol 1994, 233:229-240.

doi:10.1186/0717-6287-47-24

Cite this article as: Chaudhuri et al:: Assessment of the phytochemical constituents and antioxidant activity of a bloom forming microalgae Euglena tuba. Biological Research 2014 47:24

\section{Submit your next manuscript to BioMed Central and take full advantage of:}

- Convenient online submission

- Thorough peer review

- No space constraints or color figure charges

- Immediate publication on acceptance

- Inclusion in PubMed, CAS, Scopus and Google Scholar

- Research which is freely available for redistribution 